\title{
Effect of Fillers on the Adhesion Properties of the Cured Unsaturated Polyester Adhesive
}

\author{
Adil K. Hussien \\ Department of Chemistry \\ Sa'ad F. Mahmood \\ College of Science/ University of Mosul \\ yyaadel@yahoo.com \\ saad66fa@yahoo.com
}

(Received 27/ 11/2013 ; Accepted $7 / 4 / 2014$ )

\begin{abstract}
Unsaturated polyester (UP) composed of maleic anhydride, phthalic anhydride and 1,2propylene glycol has been prepared as an adhesive base component. Fillers are widely used in order to reduce cost and to control shrinkage in adhesive formulations.

Four types of fillers of the same particle size $(50 \mathrm{mesh})$ and different chemical properties, silica, alumina, talc, and kaolinwere used. The fillers were mixed with the unsaturated polyesterprepolymer in various contents $(5,10,20,30$ and 40) part per hundred parts of resin (phr). Their effects on different adhesion properties have been investigated.

Experimental results show, in general, that, the adhesion strength of the unsaturated polyester adhesive measured by the standard lap- shear test method (ASTM D-1002) was increased in accordance with the increase of the weight percentage of the loaded filler. Best results as an adhesion strength were obtained with the kaolin filler.
\end{abstract}

Keywords : Unsaturated Polyester, Adhesive, Fillers, Silica, Alumina, Talc, Kaolin.

\section{تأثير المائلت عل خولص اللصق للوالصق البولي أسترات غير المشبهة المقسة}

\section{ll}

حضر البولي لستر غير المشع الأولي (الذي يمل المكون الأسلسي لللاصق) من قاعل النهيدريد الماليك و النهيدريدالفثاليك مع 2,1 -بروبلين كلايكول. من مساوئ لواصق البولي لسترات غير المشبعة هي الانكملث العالي غسبيا، لذك الك

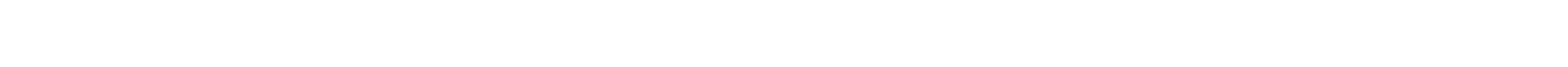
المشبعة ـ لستخمت أربعة أنواع من المالئت ذوات صفلت وترلكيب كيميائية مختلفة ولكن بحجم حبيبي ولحد (50 mesh) هي في

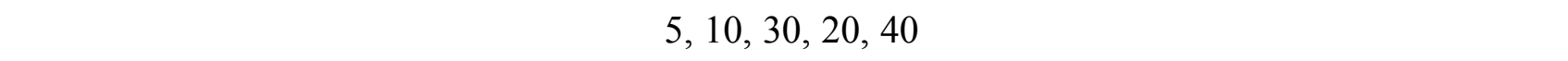

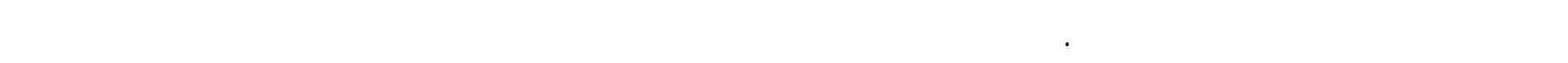
القص القيلسية الأمريكية (ASTM D-1002) حصول زياة واضحة في قوة الالتصق مع زيادة ترلكيز المائت المضافة وأن أفضل النتائج المستحصلة كانت مع الكاؤولين.

\section{INTRODUCTION}

Unsaturated polyesters, are a commercial thermosetting resins widely used as a neat (Ayman et al., 2006), with fillers (Lu et al., 2006), and reinforced by fibers (Burgueno et al., 2004). Many inert solids (fillers) are added to polyesters to improve their mechanical properties and decrease cost. These materialsare called fillers or reinforces such as calcite, alumina, clays, mica, or fiberglass (Cayli and Kusefoglu, 2006). 
Asbestos, either powdered or in fiber form, imparts heat resistance; aluminum trihydrate and talcum act as flame retarders; mica gives excellent electrical properties. Powdered minerals such as silica or china clay are often used to improve water resistance. Aluminum and silver powders or flakes are used to improve the thermal and electrical conductivities for adhesives (Tess and Poehlein,1985).

Thermal properties of adhesives were improved the by addition of metal fillers, while their influence on the mechanical properties of the adhesive joints are not clear (Kahramana et al., 2008).

Unsaturated polyesters are used to seal similar and dissimilar materials (ass, metals, nonmetals, wood, plastics, or ceramics), some shrinkage will occur through curing at room temperature. Unsaturated polyester resins are the most common binders in composite because of the low viscosity, rapid curing at room and even negative temperatures, good compatibility with mineral fillers and reinforcing fiber materials, as well as their ability to transformed into cross- linked polymers by polymerization or polycondensation reaction (Murafa et al., 1996).

Fillers have a tendency to increase resin viscosity. They are generally mixed into the resin with any pigments or catalysts. As a rule of thumb, no more than $40 \%$ of the entire mixture should be filler, or properties will be reduced.

The main justification for using fillers is to reduce the material costs. However, if proper amounts are used, they can reduce curing shrinkage and improve surface appearance. Reducing shrinkage with the aid of fillers can also improve water resistance and weathering properties (Gregor and Greenwood,1980).

By means of both chemical and physical modifications new unsaturated polyester resin can be obtained, it was possible to improve the end-use properties of the final products, and find new applications.

The objective was to investigate the influence of the filler content on the mechanical performance of steel single-lap joints bonded with unsaturated polyester resins as well as their effects on different adhesion properties.

\section{Chemicals and Reagents:}

\section{EXPERIMENTAL}

Maleic anhydride (Fluka), phthalic anhydride (BDH), 1,2-propylene glycol (Fluka), Styrene (Fluka), Benzoyl peroxide (BDH), N,N-dimethyl aniline $(\mathrm{BDH})$, were purified via using the standard procedures(Armarego and Perrin,1996). Silica, alumina, talc and kaolin (BDH) are used as received.

\section{Procedure}

\section{Preparation of Unsaturated Maleate/ O-Phthalate/ 1,2-Propanediol} Polyester Prepolymer (UP)

$98 \mathrm{~g}(1.0 \mathrm{~mol})$ of Maleic anhydride, $148 \mathrm{~g}(1.0 \mathrm{~mol})$ of phthalic anhydride, and $160 \mathrm{~g}$ $(2.1 \mathrm{~mol})$ of 1,2-propanediol are placed in a three-necked flask equipped with a mechanical stirrer, nitrogen inlet, and a distillation head connected to a condenser and a receiver flask. The reaction was preheated at $160^{\circ} \mathrm{C}$. Water begins to distill, the temperature then raised gradually to $190^{\circ} \mathrm{C}$. The polycondensation is stopped (after about $15 \mathrm{~h}$ ) when the acid number of the reaction mixture reaches 50 (Rogers and Long, 2003; Hussien, 2005).

\section{Carboxyl End group Chemical Titration}

A sample of polyester (ca. 1 g., exactly weighed) is dissolved in $20 \mathrm{~mL}$ toluene- ethanol mixture (1/1 vol.) and titrated against a solution of $\mathrm{KOH}$ in ethanol $(0.05 \mathrm{~mol} / \mathrm{L})$ using a potentiometric titration. A blank titration must be performed under the same conditions.

The result (acid content) is normally expressed in $\mathrm{mmol} \mathrm{COOH} / \mathrm{g}$. polyester which also given as the "acid number," [Acid number $=($ number of $\mathrm{mmol} \mathrm{COOH} / \mathrm{g}$. polyester $) \times 56.106$.] $($ Rogers and Long, 2003). 


\section{Formulations of UP with Fillers}

Alumina, silica, kaolin, and talc were grounded into a powder form. The filler powder was sieved and the average particle dimension size less than 300 micron ( $\sim$ mesh 50$)$ was loaded into the unsaturated polyester prepolymer in various contents $5,10,20,30$, and 40 part per hundred parts of resin (phr), (2:1) ratio of styrene: Up as cross -linking agent. $1.5 \%$ of benzoyl peroxide as initiator and $0.75 \%$ of $\mathrm{N}, \mathrm{N}$-dimethyl aniline as accelerator were added for cure completion of adhesives.

\section{Preparation of the Test Specimens: Cleaning and Pretreatment:}

Metallic test specimens were prepared prior to adhesive bonding according to ASTM-D 2651 (preparation of metal surfaces for adhesive bonding).

\section{Gluing:}

The test specimens were glued together by the adhesive and the blend to be tested. Proper spreading, especially uniform distribution of the liquid adhesive on the surfaces was essential. Test specimens to be glued were pressed and kept under pressure of $\left(100-250 \mathrm{~g} / \mathrm{cm}^{2}\right)$ during the major part of the curing ( 24 hours).

It is important that all flash be carefully removed from the edges of the specimen. Then the applied pressure was removed and the adhesive was tested after 72 hours.

\section{Determination of Gel Time:}

It was determined by estimating the time from the onset of cure on mixing the two parts, i.e. introduction of a catalyst and an accelerator (hardener) into a liquid adhesive, to the gel point (gelation occurrence) where the mixture becomes significantly less able to flow under light forces. Determination followed various standard methods(British standard-B, 1980) and(British standard-D, 1980).

\section{Mechanical Testing:}

Universal testing machine Amsler type-FM 2750 Wolpert was used for testing lap shear strength.

\section{Failure mode:}

After the specimens were tested, the fractured surfaces of the adhesive joint were examined optically or visually to determine the locus of fracture of the bonded parts.

\section{RESULTS AND DISCUSSION}

Fillers have a tendency to increase adhesive viscosity (Randklev, 1987). The fillers used in unsaturated polyester adhesive impart a sufficient viscosity to the adhesive to make it readily workable.

In selecting a proper filler, a number of parameters and properties must be taken into consideration. particle size must be considered since it affect the properties of the cured resin. Fillers of large particle size, if not dispersed/suspended properly, may tend to settle, resulting in an uneven distribution of the filler during cure, therefore the adhesive filler should be finely divided in order to facilitate thorough mixing of the filler and the polymerizable resin.

To investigate the effect of the added fillers on the adhesion properties of the cured unsaturated polyester adhesive, lap shear test was performed, as well as failure mode diagnosis and gel time estimation. Most fillers used are inorganic and are usually based on naturally occurring mined minerals.

The fillers used in this research are classified into two categories: silicates, which includes talc and kaolin; oxides, which includes alumina and silica.

Kaolin is a mineral clay, with the chemical composition (hydrated aluminum silicate, $\left.\mathrm{Al}_{2} \mathrm{Si}_{2} \mathrm{O}_{5}(\mathrm{OH})_{4}\right)$. Properties of fine particle size, platy shape, inertness, non-toxicity, and high brightness and whiteness make it a most versatile mineral, with applications in a wide variety of 
industries. kaolin is used in adhesive, caulk and sealant systems to control structure, consistency and body.

Unsaturated polyester prepolymer is prepared with a certain molecular weight $(\sim 1100 \mathrm{~g} / \mathrm{mol})$ by controlling the acid number $(\sim 50)$ of the polycondensation reaction mixture.

Results of lap shear strength (adhesive strength) and gel time for unsaturated polyester adhesive of different kaolin ratios are shown in (Table 1).

Table 1: Results of lap shear strength (adhesive strength) and gel time for unsaturated polyester adhesive of different kaolin ratios

\begin{tabular}{|c|c|c|c|c|c|}
\hline \multirow{2}{*}{$\begin{array}{c}\text { Ratios of Kaolin } \\
\text { added to UP, phr }\end{array}$} & \multirow{2}{*}{ Gel time, min } & \multicolumn{4}{|c|}{ Lap Shear Strength (Adhesive Strength), N/Inch } \\
\cline { 3 - 6 } & & Specimen 1 & Specimen 2 & Specimen 3 & Average \\
\hline 0 & 2.5 & 4970 & 5290 & 5340 & 5200 \\
\hline 5 & 2.3 & 5700 & 6000 & 5400 & 5700 \\
\hline 10 & 2.1 & 7200 & 5800 & 5600 & 6200 \\
\hline 20 & 2.1 & 5900 & 7000 & 7800 & 6900 \\
\hline 30 & 1.5 & 9200 & 10700 & 8900 & 9600 \\
\hline 40 & 1.9 & 9800 & 8200 & 8400 & 8800 \\
\hline
\end{tabular}

Table (1) illustrate the results of gel time and lap shear strength for unsaturated polyester adhesive of different kaolin ratios. Gel time was reduced in accordance with the increase in curing activity. It is clear that the adhesive strength for kaolin ratio of 30 phrunsaturated polyester adhesive was the higher, followed by the ratio of kaolin of 40 phrunsaturated polyester adhesive, whereas it was the weakest for ratio of kaolin of 5 phrunsaturated polyester adhesive .

Table (2) showed results of increase in adhesive strength due to different kaolin ratios added to unsaturated polyester and failure mode.

Table 2: Results of increase in adhesive strength due to different kaolin ratios added to unsaturated polyester and failure mode

\begin{tabular}{|c|c|c|c|}
\hline $\begin{array}{c}\text { Ratios of Kaolin added to UP, } \\
\text { phr }\end{array}$ & $\begin{array}{c}\text { Adhesive Strength, } \\
\text { N/Inch }\end{array}$ & \%Increase & Failure Mode \\
\hline 0 & 5200 & 0 & Adhesion failure \\
\hline 5 & 5700 & 10 & Adhesion failure \\
\hline 10 & 6200 & 20 & $\begin{array}{c}30 \% \text { Cohesion } \\
70 \% \text { Adhesion }\end{array}$ \\
\hline 20 & 6900 & 33 & $\begin{array}{c}30 \% \text { Cohesion } \\
70 \% \text { Adhesion }\end{array}$ \\
\hline 30 & 9600 & 84 & $\begin{array}{c}60 \% \text { Cohesion } \\
40 \% \text { Adhesion }\end{array}$ \\
\hline 40 & 8800 & 69 & $\begin{array}{c}40 \% \text { Cohesion } \\
60 \% \text { Adhesion }\end{array}$ \\
\hline
\end{tabular}

The increasing in adhesive strength due to addition of kaolin ratio of $30 \mathrm{phr}$ unsaturated polyester adhesiveis $84 \%$ which is the best result. The joints fail in $60 \%$ cohesive mode (failure within the adhesive) which indicates that the adhesion of the interior part of the adhesive was weaker than that of the metal surface.

Talc is a mineral composed of hydratedmagnesiumsilicate with the chemical formula $\mathrm{H}_{2} \mathrm{Mg}_{3}\left(\mathrm{SiO}_{3}\right)_{4}$ or $\mathrm{Mg}_{3} \mathrm{Si}_{4} \mathrm{O}_{10}(\mathrm{OH})_{2}$. Talc is the softest mineral, It is mainly used as a filler. The platy shape of talc particles can increase the stiffness of products. It can also increase the heat resistance of these products and reduce shrinkage. Talc can improve the strength of the finished product. 
Results of lap shear strength and gel time for unsaturated polyester adhesive of different talc ratios are shown in Table 3.

Table 3: Results of lap shear strength (adhesive strength) and gel time for unsaturated polyester adhesive of different talc ratios

\begin{tabular}{|c|c|c|c|c|c|}
\hline \multirow{2}{*}{$\begin{array}{c}\text { Ratios of Talc added } \\
\text { to UP, phr }\end{array}$} & \multirow{2}{*}{ Gel time, min } & \multicolumn{4}{|c|}{ Lap Shear Strength (Adhesive Strength), N/Inch $\mathbf{2}^{\mathbf{2}}$} \\
\cline { 3 - 5 } & & Specimen 1 & Specimen 2 & Specimen 3 & Average \\
\hline 0 & 2.5 & 4970 & 5290 & 5340 & 5200 \\
\hline 5 & 3.2 & 6800 & 7500 & 8100 & 7400 \\
\hline 10 & 3.0 & 6700 & 6800 & 5700 & 6400 \\
\hline 20 & 2.5 & 8500 & 8700 & 8300 & 8500 \\
\hline 30 & 2.1 & 9900 & 9600 & 8900 & 9400 \\
\hline 40 & 2.1 & 9800 & 9300 & 8500 & 9200 \\
\hline
\end{tabular}

Table (3) shows that the adhesive strength for ratio of talc of $30 \mathrm{phr}$ unsaturated polyester adhesive was the higher, followed by the ratio of talc of $40 \mathrm{phr}$ unsaturated polyester adhesive, whereas it was the weakest for ratio of talc of $10 \mathrm{phr}$ unsaturated polyester adhesive.

Table (4) showed results of increase in adhesive strength due to different talc ratios added to unsaturated polyester and failure mode.

Table 4: Results of increase in adhesive strength due to different talc ratios added to unsaturated polyester and failure mode

\begin{tabular}{|c|c|c|c|}
\hline $\begin{array}{c}\text { Ratios of Talc added to UP, } \\
\text { phr }\end{array}$ & $\begin{array}{c}\text { Adhesive Strength, } \\
\text { N/Inch }\end{array}$ & \% Increase & Failure Mode \\
\hline 0 & 5200 & 0 & Adhesion failure \\
\hline 5 & 7400 & 42 & $\begin{array}{c}30 \% \text { Cohesion } \\
70 \% \text { Adhesion }\end{array}$ \\
\hline 10 & 6400 & 23 & $\begin{array}{c}30 \% \text { Cohesion } \\
70 \% \text { Adhesion }\end{array}$ \\
\hline 20 & 8500 & 63 & $\begin{array}{c}40 \% \text { Cohesion } \\
60 \% \text { Adhesion }\end{array}$ \\
\hline 30 & 9400 & 80 & $\begin{array}{c}60 \% \text { Cohesion } \\
40 \% \text { Adhesion }\end{array}$ \\
\hline 40 & 9200 & 77 & $\begin{array}{c}60 \% \text { Cohesion } \\
40 \% \text { Adhesion }\end{array}$ \\
\hline
\end{tabular}

The maximum increasing in adhesive strength due to addition of talc ratio of 30 phrto unsaturated polyester adhesive is $80 \%$. The joints fail in $60 \%$ cohesive mode (failure within the adhesive) as a precede ratio which indicates that the adhesion of the metal surface was stronger than that of the interior part of the adhesive.

Alumina is a mineral of the chemical formula $\mathrm{Al}_{2} \mathrm{O}_{3}$. Being fairly chemically inert and white, alumina is a favored filler for plastics and other materials. Alumina can Improve abrasion resistance and thermal conductivity.

Results of lap shear strength and gel time for unsaturated polyester adhesive of different alumina ratios are shown in Table 5. 
Table 5: Results of lap shear strength (adhesive strength) and gel time for unsaturated polyester adhesive of different alumina ratios

\begin{tabular}{|c|c|c|c|c|c|}
\hline \multirow{2}{*}{$\begin{array}{c}\text { Ratios of Alumina added } \\
\text { to UP, phr }\end{array}$} & \multirow{2}{*}{$\begin{array}{c}\text { Gel time, } \\
\text { min }\end{array}$} & \multicolumn{4}{|c|}{ Lap Shear Strength (Adhesive Strength), N/Inch } \\
\cline { 3 - 6 } & & Specimen 1 & Specimen 2 & Specimen 3 & Average \\
\hline 0 & 2.5 & 4970 & 5290 & 5340 & 5200 \\
\hline 5 & 2.9 & 5800 & 5600 & 4800 & 4100 \\
\hline 10 & 2.5 & 5500 & 5900 & 5200 & 5500 \\
\hline 20 & 2.1 & 8700 & 7800 & 8500 & 8300 \\
\hline 30 & 2.2 & 7300 & 7800 & 6800 & 7300 \\
\hline 40 & 3.0 & 3700 & 3800 & 4900 & 5400 \\
\hline
\end{tabular}

Table (5) shows that the adhesive strength for alumina ratio of 20 phrunsaturated polyester adhesive was the higher, followed by the ratio of alumina of $30 \mathrm{phr}$ unsaturated polyester adhesive, whereas it was the weakest for ratio of alumina of 5 phralumina unsaturated polyester adhesive.

Table (6) showed results of increase in adhesive strength due to different alumina ratios added to unsaturated polyester and failure mode.

Table 6: Results of increase in adhesive strength due to different alumina ratios added to unsaturated polyester and failure mode

\begin{tabular}{|c|c|c|c|}
\hline $\begin{array}{c}\text { Ratios of Alumina added to } \\
\text { UP, } \mathbf{p h r}\end{array}$ & $\begin{array}{c}\text { Adhesive Strength, }_{\text {N/Inch }}{ }^{2} \\
\text { \% Increase }\end{array}$ & Failure Mode \\
\hline 0 & 5200 & 0 & Adhesion failure \\
\hline 5 & 5400 & 4 & Adhesion failure \\
\hline 10 & 5500 & 6 & Adhesion failure \\
\hline 20 & 8300 & 60 & $\begin{array}{c}40 \% \text { Cohesion } \\
60 \% \text { Adhesion }\end{array}$ \\
\hline 30 & 7300 & 40 & $\begin{array}{c}30 \% \text { Cohesion } \\
70 \% \text { Adhesion }\end{array}$ \\
\hline 40 & 4100 & -21 & Cohesion failure \\
\hline
\end{tabular}

Best result for adhesive strength was obtained for alumina ratio of $20 \mathrm{phr}$ unsaturated polyester adhesive with $60 \%$ increase. The joints fail in $40 \%$ cohesive mode: $60 \%$ adhesive mode which indicates that the adhesion of the metal surface was stronger than that of the interior part of the adhesive.

Silica is a mineral composed of silicone dioxide with the chemical formula $\mathrm{SiO}_{2}$. Silica is commonly used as a filler in paints, plastics, rubber, adhesives, putty and sealants. It is ideal for general bonding and filleting. Often used in combination with other fillers, it can be used to improve strength, abrasion resistance, and consistency of fairing compounds, resulting in a tougher, smoother surface.

Results of lap shear strength and gel time for unsaturated polyester adhesive of different silica ratios are shown in (Table 7).

Table 7: Results of lap shear strength (adhesive strength) and gel time for unsaturated polyester adhesive of different silica ratios

\begin{tabular}{|c|c|c|c|c|c|}
\hline \multicolumn{4}{|c|}{ Lap Shear Strength (Adhesive Strength), N/Inch } & Gel time, min & $\begin{array}{c}\text { Ratios of Silica added } \\
\text { to UP, phr }\end{array}$ \\
\hline Average & Specimen 3 & Specimen 2 & Specimen 1 & & 0 \\
\hline 5200 & 5340 & 5290 & 4970 & 2.5 & 5 \\
\hline 4800 & 4300 & 5400 & 4800 & 3.2 & 10 \\
\hline 6900 & 6200 & 7000 & 7600 & 2.3 & 20 \\
\hline 7200 & 7700 & 8100 & 8300 & 2.2 & 30 \\
\hline 6700 & 7400 & 6900 & 7300 & 2.5 & 40 \\
\hline
\end{tabular}


Table (7) shows that the adhesive strength for alumina ratio of $20 \mathrm{phr}$ unsaturated polyester adhesive was the higher, followed by the ratio of alumina of $30 \mathrm{phr}$ unsaturated polyester adhesive, whereas it was the weakest for aluminaratio of $5 \mathrm{phr}$ unsaturated polyester adhesive.

Table (8) showed results of increase in adhesive strength due to different silica ratios added to unsaturated polyester and failure mode.

Table 8: Results of increase in adhesive strength due to different silica ratios added to unsaturated polyester and failure mode

\begin{tabular}{|c|c|c|c|}
\hline Failure Mode & $\%$ Increase & $\begin{array}{c}\text { Adhesive Strength, } \\
\text { N/Inch }{ }^{2}\end{array}$ & $\begin{array}{l}\text { Ratios of Silica } \\
\text { added to UP, phr }\end{array}$ \\
\hline Adhesion failure & 0 & 5200 & 0 \\
\hline Cohesion failure & -8 & 4800 & 5 \\
\hline $\begin{array}{l}30 \% \text { Cohesion } \\
70 \% \text { Adhesion }\end{array}$ & 33 & 6900 & 10 \\
\hline $\begin{array}{l}40 \% \text { Cohesion } \\
60 \% \text { Adhesion } \\
\end{array}$ & 54 & 8000 & 20 \\
\hline $\begin{array}{l}30 \% \text { Cohesion } \\
70 \% \text { Adhesion }\end{array}$ & 38 & 7200 & 30 \\
\hline $\begin{array}{l}25 \% \text { Cohesion } \\
75 \% \text { Adhesion }\end{array}$ & 29 & 6700 & 40 \\
\hline
\end{tabular}

Best result for adhesive strength was obtained for silica ratio of $20 \mathrm{phr}$ unsaturated polyester adhesive with $54 \%$ increase. The joints fail in $40 \%$ cohesive mode: $60 \%$ adhesive mode which indicates that the adhesion of the metal surface was stronger than that of the interior part of the adhesive.

Fig. (1) shows the behavior of the adhesion properties (adhesive strength) for unsaturated polyester formulated with fillers of the same size and shape, kaolin, talc, alumina and silica respectively, as a function of filler loading.

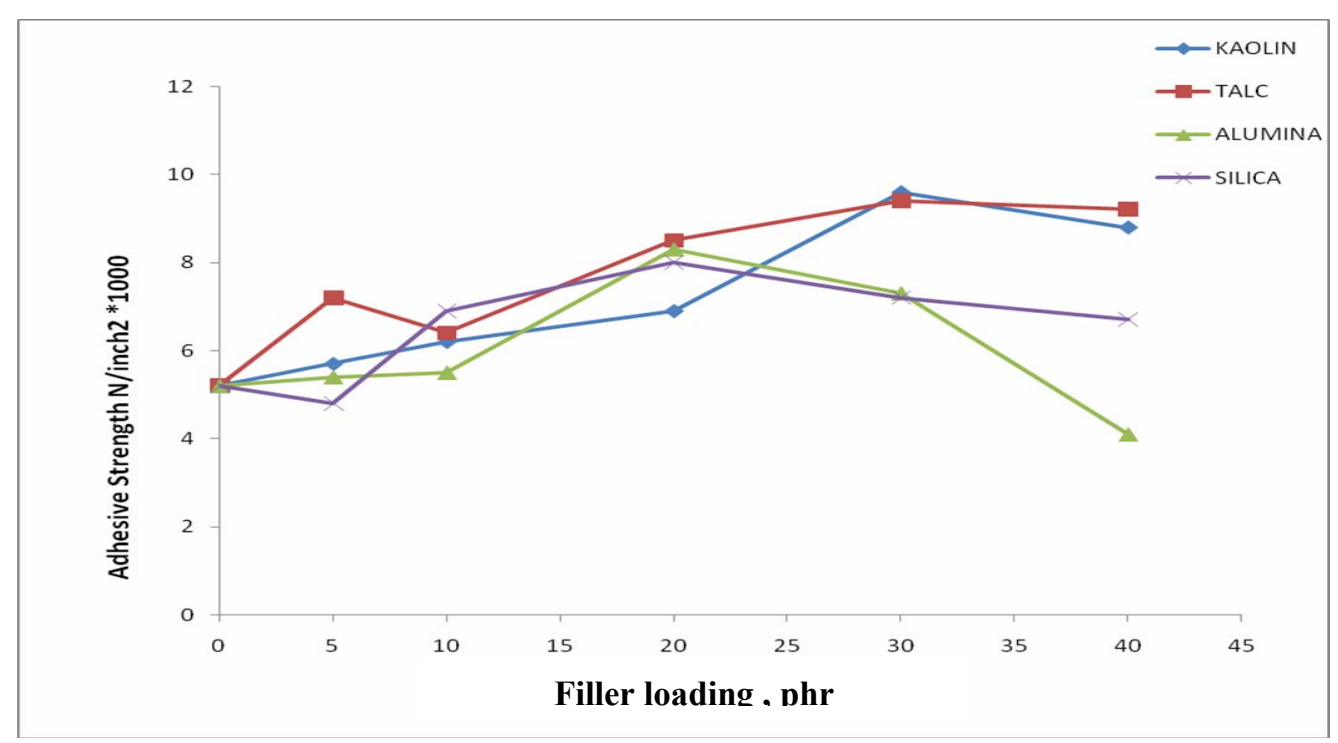

Fig. 1: The behavior of the adhesion properties with fillers

Formulation of the unsaturated polyester adhesives with various types of fillers causes obvious variation in adhesion properties (increase in adhesive strength) due to the following reasons (Braga et al., 2005; Hayaty and Beheshti, 2004; Petrie, 2007):

1.Unsaturated polyester adhesives of lower shrinkage can be obtained by addition of fillers.

2.As the filler loading increases, this shrinkage may press filler particles against each other, increasing particle-particle friction.

3.Fillers may lower cross linking density during cure operation. 
4.Adhesives formulated with various fillers can modify their thermal expansion characteristics and limit internal stresses.

\section{CONCLUSIONS}

In general, the effects provided by fillers are more dependent on the weight percent incorporated rather than the type. The more common fillers in use today are silica, talc, alumina and clays.

It was found that the failure strength of the adhesive increased in accordance with the increase of the weight percentage of the filler to a certain limit.

As a rule of thumb, no more than $30 \%$ of the entire mixture should be filler, or properties will be reduced.

\section{REFERENCES}

Armarego, W.L.F.; Perrin, D.D. (1996). "Purification of Laboratory Chemicals". $4^{\text {th }}$ ed., Butterworth Heinemann, London,

Ayman, M.A.; Abdel-Raouf, M.E.; Elsaeed, S.M.; Abdel-Azim, A.A. (2006). Curable resins based on recycled poly (ethylene terephthalate) for coating applications. Progress in Organic Coatings, 55, 50-59.

Braga, R.R.; Ballester, R.Y.; Ferracane, J.L. (2005). Factors involved in the development of polymerization shrinkage stress in resin-composites: A systematic review. Dental Material, 21, 962-70.

British Standers 2782-8: Method 835 B: (1980). Determination of gelation time of polyester resins (manual method).

British Standers 2782-8: Method 835 D: (1980). Determination of gelation time of thermosetting resins using a hot plate.

Burgueno, R.; Quagliata, M.J.; Mohanty, A.K.; Mehta, G.; Drzal, L.T.; Misra, M. (2004). Loadbearing natural fiber composite cellular beams and panels. Composites Part A-Appl. Sci. and Manufacturing, 35, 645-656.

ÇayliGökhan, KüsefoğluSelim, (2006). Thermal and mechanical behavior of unsaturated polyesters filled with phase change materials. J. Appl. Polymer Sci.,100, 832-838.

Gregor, E.A.Mac.; Greenwood, C.T. (1980). "Polymers in Natures". John Wiley and Sons, Chechester, $362 \mathrm{p}$.

Hayaty, M.; Beheshti, M.H. (2004). Shrinkage, cure characterization and processing of unsaturated polyester resin containing pvac low-profile additive. Iranian Polymer J. 13(5), 389-396.

Hussien, A.K. (2005). The development of new adhesives based on cross- linked unsaturated polyesters. Ph.D. Thesis, Mosul University, Mosul, 10 p.

Lu, W.; Lin, H.; Wu, D.; Chen, G. (2006). Unsaturated polyester resin/graphite nanosheet conducting composites with a low percolation threshold. Polymer, 47, 4440-4444.

Murafa, A.V.; Bobyreva, N.I.; Khozin, V.G. (1996). Modification of polyester resins with active mineral fillers . Mechanics of Composite Materials, 32(1), 86-89.

Petrie, E.M. (2007). "Hand Book and Sealants". $2^{\text {nd }}$ ed., McGraw-Hill Companies, Inc, NewYork, $76 \mathrm{p}$.

Ramazan, K.; Sunarb, M.; Yilbas, B. (2008). Influence of adhesive thickness and filler content on the mechanical performance of aluminum single-lap joints. J. Materials Processing Techno. 205, 183-189.

Rogers, M.S.; Long, T.E. (2003). "Synthetic Methods In Step-Growth Polymers". Wiley Interscience, New Jersey, $101 \mathrm{p}$.

Tess Roy, W.; Poehlein, G.W. (1985). "Applied Polymer Science". $2^{\text {nd }}$ edn. American Chemical Society, Washington, D.C, 234p. 